\title{
Phenomenology of a Photograph, Or: How to use an Eidetic Phenomenology
}

\author{
L. Sebastian Purcell
}

\section{A Promissory Note}

The present essay aims to make good on what turns out to be a promissory note signed by Roland Barthes in Camera Lucida. There, in the opening pages, he writes that he wished to identify photography's "essential features" through a phenomenology, and that "[he] wanted to learn at all costs what Photography was "in itself'" (3). Yet, in the years that have passed, it has become increasingly clear that he neither accomplished this aim, nor that he ever really intended to do so. Jacques Derrida shows quite clearly that the work fails to achieve its aims, and that it enacts this failure by contradicting its claims to universality. ${ }^{1}$ Patrick Maynard similarly argues that Camera Lucida has really nothing to say about photography at all, and is instead a meditation on representation and mourning. ${ }^{2}$ Finally, Nancy Shawcross provides what is perhaps the most compelling reason for this failure, namely that the work is an experiment in what Barthes called the "third form" of literature, between an essay and a novel, so that any straightforward extrapolation is bound to be mistaken. ${ }^{3}$ The result is that scholarship on this matter has tended to focus on what can be salvaged from the project, if anything, for reflection on photography. ${ }^{4}$ Yet, and here is the question I want to pursue, what would have resulted had Barthes stuck to his stated aim of pursuing an eidetic phenomenology? Has something been overlooked in the phenomenological tradition, which has favored painting almost exclusively in 
the visual arts? Is there something troubling in the photograph for the status of the phenomenon? Does it destabilize its shining in-and-from itself? If so, how, and what are the consequences?

What I hope to suggest here is that there are eight eidetic features of a photograph, and though each will receive its own attention, a central thread unites them, which I want to capture as the transformative capacity of the photograph with respect to the aesthetic field. The consequences of identifying these features, I hope to show, bear directly on the phenomenology of time, the possibility of technological events, and the status of truth (especially in light of Heidegger's sense of alētheia). ${ }^{5}$ Finally, if I am successful in this endeavor, I shall have established a new way to use eidetic phenomenologies: not for Husserl's original aim of executing a rigorous science but, in a more Derridian spirit, as a way to destabilize consensus. This last consequence, however, points to what is likely the most obvious objection to this enterprise: am I really so naïve as to think that eidetic phenomenologies are still possible? I want to begin, then, by addressing what is in fact a cluster of objections to eidetic phenomenology.

\section{A Return to the "Eidetic"}

One could group the criticisms of eidetic phenomenology under two main headings: those that are convinced the project is impossible, and those that would not want it to succeed if it could. The former camp tends to focus either on the strict impossibility of the reduction (in either its transcendental or eidetic phases) or its uselessness. ${ }^{6}$ The latter camp is less concerned with the theoretical problems than their ethical and political danger. Here the present aim meets with criticisms by feminists, and race and queer theorists. ${ }^{7}$ Not only does the project seem to be doomed to failure, they argue, but also it would not be desirable even if it could succeed. The universalizing or "essentialist" claims of such a project suffocate diversity, which is necessary 
for our pluralistic and increasingly globalized modern world. What is needed is not another work that would close down paths to liberation, but one that will find revolutionary potential.

My response is also two-fold. I note, first, that the proposal here is that a corrigible eidetic phenomenology can be undertaken for the photograph (not for humans, or women, or men, or animals). Paul Ricoeur already made clear that it is possible to undertake a phenomenological investigation as a hermeneutic philosopher, shifting the onus of the eidetic reduction from an act the phenomenologist undertakes to the aim to be accomplished through intelligent exchange and scholarship. ${ }^{8}$ Recently, Claude Romano has demonstrated that the theory-ladenness, or in his terms the irremediable mediacy, of phenomena is something that phenomenology itself is meant to address, so that incorrigibility has never been part of the phenomenological aim. ${ }^{9}$ The present eidetic phenomenology, then, follows in this vein, and so is not committed to a strong form of realism, but is an admittedly fallible enterprise. Second, I argue that, if done correctly, it is precisely by attending to eidetic features that one will be able to break up some of the dogmas of the phenomenological hermeneutic tradition. Since this last point may not be totally clear, I want to address it now with a bit more care.

The heart of my proposal turns on a retrieval of the character of the phenomenological "eidos." Normally, this eidos is understood to be equivalent to the Kantian a priori, such that it expresses those features of a phenomenon that are both universal and necessary. ${ }^{10}$ Husserl, in his late work Experience and Judgment appears to confirm this point. In detailing the method of essential seeing (Wesenserschauung) he writes: "the essence proves to be that without which an object of a particular kind cannot be thought, i.e., without which the object cannot be intuitively imagined as such" (341). Yet, what must be grasped is that Husserl only understands the "seeing" of essences as the terminal point in an arc that moves from judgment about empirical 
particulars (§§74-80), through empirical generalities (§§81-85) to the eidetic (§§86-90). Focusing specifically on this last transition, one finds that, in a fashion reminiscent of David Hume's account of causation, Husserl argues that empirical generalities are those which are formed through repeated psychological association $(\S 82) .{ }^{11}$ The extent of this generality may be extended through one's imagination (§86), but even in this case "the unity of the empirically acquired species and the higher genus is a 'contingent' one" (339). Free variation, which serves as the foundation for essential seeing, thus bears the responsibility for freeing the empirically general "from its character of contingency" (340). By an act of volition one varies the phenomenon such that "[i]t then becomes evident that a unity runs through this multiplicity of successive figures ... [and] an invariant is necessarily retained as the necessary general form, without which an object such as this thing, as an example of its kind, would not be thinkable at all" (341).

Though the conclusion appears to remain within the Kantian account of the a priori (i.e. as both universal and necessary), it is the trajectory that Husserl details that opens the conceptual space for what I want to call the "amplitive" features of phenomena. These features are the merely invariant, and thus stand opposed to the traditionally eidetic, which are both universal and necessary. ${ }^{12}$ Given the way that the move to the phenomenological essence is achieved, it is possible that between empirical generalities, which are contingent, and eidoi, which have had that contingency removed, there remain phenomena with features that are invariant but that are not necessary. They might thus retain a certain amount of contingency, but this contingency is of such a kind that it is possible to prescribe rules to all empirical particulars of that sort. 
In order both to make this possibility clearer, and to provide phenomenological grounds for accepting my thesis, which is not explored by Husserl, consider the following phenomenological case: The Girl and the Vulture.

Figure 1: Untitled http://digitalfilmmaker.net/bang/bang_frame.html

In 1994 Kevin Carter won the Pulitzer Prize for this photograph of a starving girl who is depicted as dragging herself toward an aid station near the village of Ayod in Sudan (Figure 1, accessible by hyperlink). Just a few paces behind her one finds a vulture, poised for her imminent death. Carter took the picture as part of his battle against apartheid, and afterwards chased the vulture away. The photo was published in The New York Times on March 26, 1993 and instantly became a symbol of human misery. As the thousands of readers wrote to ask about the fate of the girl, all Carter could answer was that he did not know about it. Though the image brought him fame and celebrity, Carter, who was always a sensitive person, could not withstand the withering criticism that followed. Two months after receiving his prize he committed suicide.

My hope is that the reader is moved somewhat by this symbol of misery. It is this feeling which caused such uproar in response to Carter's image, and which haunted Carter himself as a man ambiguously responsible for the girl's fate. That feeling attests to the phenomenological warrant for the distinction between the amplitive and the eidetic. One need only ask: what would the case have been had there been no girl in the photo? Certainly it would not have been very remarkable. A lone vulture standing off center in a mostly dirt field, a few hay bales in the background. Carter would not have published it. It would not have created such a furor. He would not have been criticized and he would not have received the Pulitzer Prize either. In all 
likelihood, Carter would be alive today. The difference between the actual photograph and this hypothetical one concerns the presence of the girl, the human form. She introduces an affective and meaningful dimension to the photograph that qualitatively transforms it into different kind image. Landscape photograph and photography with humans, especially human faces, are fundamentally distinct visual media. This is a point that one can establish by appealing to the lived experience (Erlebnis) of first-person consciousness.

Now I want to take one more step in this reflection. Could this affective difference between landscape photography and photography with the human form be captured by an eidetic phenomenology? Can this distinction be captured by appealing to the criteria of universality and necessity? The answer to both questions, I think, is negative. In the eidetic phenomenology to follow, I shall argue that one of the features of a photograph is that it must be about something, even if that something is nothing (as is the case with abstract photography). In short, I shall argue that photographs are at a minimum emptily intentioned. But this eidetic feature shows simultaneously that it is not at all necessary for the photograph to be about something determinate - especially something as particular as the human form or human face. It is, of course, these latter kinds of considerations to which Barthes attends in his famous reflections on the "Winter Garden" photograph, and equally make possible an understanding of artistic developments such as the significance of Jeff Wall's enormous lightboxes. ${ }^{13}$ These qualitative dimensions of the photograph themselves are contingent, since they need not appear, yet are at the same time invariant, since the character of the human face in a photograph has its own reliable and stable features. An eidetic phenomenology of the photograph, then, cannot capture the qualitative distinction between landscape photography and photography of the human form. 
My proposal here, by contrast, is to attend to the strictly eidetic features of the photograph. Still, I remain entirely unconvinced that the eidetic approach would be at all useful for addressing photography. Too much of what is pertinent to photography falls through the coarse sieve of eidetic phenomenology, and it is because attention to the simply invariant but not necessary features of phenomena widens our descriptive concern that these features deserve to be called "amplitive." The immediate implication of this distinction, then, is that eidetic phenomenology cannot provide one with a rigorous science in the way Husserl conceived, since what is arguably most pertinent about phenomena cannot be grasped eidetically. This means that the eidetic as a field of inquiry will either have to be found a new home or discarded as antithetical to the aims of philosophers. Here, I shall try to make a case for the former, since it appears to me that there is a relation of supervenience of the amplitive on the eidetic. These remarks, then, should suffice to diffuse any initial incredulity at the prospect of an eidetic phenomenology, so it makes sense now to turn to the matter at hand by beginning with what is probably most agreed on about a photograph: the inscriptive character of photographic phenomena.

\section{Image Inscription}

At base a photograph has always been a process of recording or inscribing. The term itself, from phōs and graphein, indicates a writing of light. What is not agreed on is the following: in what precisely does this representative quality consist?

For some time it has been noted that something common opinion considers essentialthe camera - needs not to be present for a photographic image. ${ }^{14}$ It is possible to obtain prints by directly exposing film to a light source. What proves essential for the image's inscription, then, is 
not the camera itself, but the character of the relation that obtains between the imaged and its exposure. What is one to make of this relation?

It might be tempting to say that the relation is a mimetic one, much like a mirror. The specter of Socrates' argument in Book X of the Republic (597a-e) looms here, since it might appear that the image is a degraded imitation of what is itself an imitation. In a similar way it seems that photos simply reproduce light waves and not even the object itself. Husserl accounts for images along these lines. First, he draws a helpful tripartite distinction among: (1) the physical image (i.e. canvas, paper, film, etc.), (2) the representing or depicting object (i.e. the patterns of colors that physically make up the image), which he calls the image object, and (3) the represented or depicted item (e.g. a smiling child), which he calls the image subject (Husserl, Phantasy 20-1). Later he argues that while "[p]erception presents the object directly," an image has a double objectivity (image object and image subject) that re-presents what is depicted (26). Humans both live through the image subject and are nevertheless aware that they perceive an image of an original that is taken to be similar. What characterizes image representation, then, is resemblance (28).

The problem with this conclusion is that the relation of an image to its original exposure can be distorted quite thoroughly in a photograph. This is possible not only with multiple exposures, but also and especially through the use of computer graphic manipulation. Furthermore, the image subject need not be of or about anything, as one finds in abstract photography. Resemblance, then, cannot characterize the representative relation of all photographs. Still, it would be good to guard against (i.e., bracket) two additional notions. First, it should not rashly be concluded that the relation is more like a hall of mirrors effect, pure simulacrum without original. ${ }^{15}$ While this may describe certain photographs, there need not be 
deliberate distortion in an image, and the present phenomenology has as yet provided no evidence for concluding that photos must be distorting. Equally, Jacques Rancière's critique of Barthes' account of the punctum, while perhaps accurate for the "artistic image," is not helpful to the present investigation of the photographic image (7). For Rancière the photograph is artistic on account of its double poetics, that is to say, on account of its involvement in the representative regime of the sayable and visible (12). Clearly the possibility of such a regime requires an intertwining of punctum, the immediate pathetic affect of the image that the photographer never fully controls, and studium, the information provided by the photograph, which Barthes proscribes. Still, my aims exceed the artistic, so this regime, which Rancière finds to be the same as, even established by, literary texts, cannot be adequate to the representative model of the photograph. I thus want to leave the representative relation open for just a bit. It is recognized that image inscription does re-present reality anew, and it makes sense to borrow Husserl's threefold distinction, since it is only his foreclosure of the photographic scope that requires him to conclude that the image always resembles its image subject. Thus, in a preliminary fashion, I characterize the representative relation merely as transformative, without as yet specifying its full sense. To spell out what this means, I want to attend to the way in which the frame of a photograph contributes to the representative quality of a photographic image.

\section{The Frame}

I look at my desk. It is given to me from this angle, in this light, at a certain distance. As I move my head, reposition my body, more of these profiles are revealed, but others disappear. It remains a desk, the same desk, because it appears as an identity in its manifold of profiles. The 
frame, it is readily granted, imposes a certain kind of limitation on this appearance, but what kind of limitation exactly?

In the lived experience of my desk, not only are more profiles available, but also those that are not presented at any given moment are nevertheless appresented. My desk appears to me, and while I cannot see its backside, it is still given to me, but only appresentatively. Jean-Luc Marion has suggested that in paintings, what is changed by the frame is that the appresented is reduced so that only the pure visible appears without remainder (68). This thesis seems to be false in both paintings and photographs. In either a photo or a painting of my desk, the image subject (in Husserl's sense) shows itself with its apperceived profiles. I would be surprised to see another photo of the desk that revealed that there was no backside, but that the desk was really made of papier-mâché glued to a piece of cardboard. One can even find this much in paintings. In Caravaggio's The Conversion of Saint Paul, I do apperceive that the horse has another side, that the man who holds the reins has a fully connected body, et cetera. The frame, then, does not enact a reduction to the purely visible, or at least not in this way. ${ }^{16}$

Rather, returning to the photograph of my desk, I recognize that while it does present me with the apperceived, what it cannot give me are any more profiles of my desk. It is true enough that I am able to perceive an indefinite number of profiles of the photograph itself, but not of what it represents (the image subject). The frame, then, freezes the proliferation of profiles, of (re-)presentations and appresentations. This is its fundamental limiting activity. Because its consequences for the representation of space and time are immediate, it is reasonable now to turn to these features of the photograph. 


\section{Spatiality or Color}

That both the image object and image subject occur spatially is clear. It could be added that while the space of the image object is three dimensional, that of the image subject may be either only two dimensional (as in abstract photos), or three dimensional, but that in this last case this space may be distorted beyond its generally apparent Euclidean form. One finds examples of this in photographs with so called fish-eye lenses. Here one begins to depart from the obvious, for what is it that signals the distortion of space in the image subject?

As a first step in the direction of an answer, note that in a photograph one has no access to depth or dimension apart from visible space. I cannot reach my hand out to feel the distance to an object, and similarly I cannot tell up from down by the use of my semicircular canals, which grant me my ordinary access to directionality. I only have variations in color, whether chromatic or achromatic, which form lines that draw dimension, and shades that signal perspective. Where none of these coalesce to form a three-dimensional gestalt, one has an image subject in two dimensions, and where the gestalt is partial, one has a distorted image. These considerations lead to one conclusion invariably: in a photograph space is color (including the achromatic), though I hasten to add that this includes the capacity on the part of the viewer to form a gestalt.

\section{Temporality}

Common sense is no guide with respect to the time of a photograph. It asserts that it has none. Yet Niepce, who is credited with the production of the first modern photograph, was not animated by any sense of producing a new mode of pictorial representation. Rather he, Daguerre, and others engaged in the project at the time were interested in fixing images that "spontaneously" formed on the ground of the camera obscura. This is to say, they wanted to fix 
an image that humans had been able to produce since what is likely the $11^{\text {th }}$ century. This matter of fixing introduces the achronic temporality, or non-sequential time, of the photograph.

The most stunning example of the time of the photograph is to be found in the case of light art performance photography. ${ }^{17}$ Here, a performer with various light forms, such as bulbs tied to the ends of ropes, or lighted body costumes, moves during the time of photographic exposure. The result traces the movement of light in the photograph, where, of course, all movements appear simultaneously (figure 2, accessible by hyperlink). Whatever the chronic length of time for the exposure - a time that always varies - the whole sequence is recorded as the moment. The image subject of a photograph, then, does have a temporal dimension. The moment is not a length of time (a chromos), but a (re)presentation of chronic temporal duration as occurring simultaneously. This effects a distortion in time, which effectively makes the time of

a photograph incompatible with the flowing nows of chronic temporality, ${ }^{18}$ and even the structure of inner time-consciousness, since retention and protention cease to become part of the lived present. $^{19}$

\section{Figure 2: Untitled}

http://www.lapp-pro.de/gallerydata/gallery 6/ mg 0705 bremen_universumneubau electron_ausschnitt.jpg

It is in this moment alone that the photograph and light performance art take place. Excluded from participation in this time are film and painting. A painter, such as Rubens, may paint a scene that occurs "at the instant," or a film may freeze on a frame, but in the former case no exposure to chronic time was necessary, and in the latter, the progression of the film itself makes up the time of the cinematic experience. The photographic representation of time, then, is distinct from both of these other media. One can gain a sense now of the way in which the 
representative process of the photograph is transformative, so I am going to return to these relational matters now with these aesthetic transformations in mind.

\section{Minimally Empty Intention}

Can there be photographs of nothing at all? Is a photograph always about something? Is it possible to eliminate the intentional dimension of photography?

There is a paranoid cliché that in the 1950s the CIA and the Museum of Modern Art colluded to promote abstract expressionism as an American tool of the Cold War. The idea seems to have been that this kind of painting could only have been used to torture people. Apart from the factual inaccuracy of this statement, which forgets that abstract art began well before the Cold War, what seems to have been explored in the broad movement known as abstract art is the capacity of paintings to empty themselves of any reference, or any intentional quality. Jackson Pollock told an interviewer that when he poured his paintings he was ever mindful to suppress any unwanted imagery: "I try to stay away from any recognizable image; if it creeps in, I try to do away with it" (Naifeh and Smith 591). Yet if one succeeds in this task, and this is the capital question, does this empty the painting of its intentional quality?

The answer I propose here is simple: no, it does not. ${ }^{20}$ Paintings and photos alike, even if one removes all identifiable reference, present one with at least a minimally empty intention. In these works, one has not the absence of intentionality, but a painting with an empty intention. This is why one can always find, as one does in clouds, all sorts of items: fish, dragons, flowers, etc. The intentional aspect remains. With abstract paintings as well as photographs, something is presented, one simply remains unable to say definitively what it is. The 'what' of the image is evacuated, but the aboutness remains. To return to Husserl's terminology, this means that the 
image subject is at most empty or void, but not that it is absent. At this point, then, it is not an unintelligent question to wonder whether and to what extent the represented is under the control of the photographer. Here the matter of Barthes' punctum returns, and I should like to address it by turning to context and technology as eidetic features.

\section{Context}

That every photograph is a cultural artifact means that it appears within a context, even if that context is unknown. It is precisely the enigma of an absent context that can make a photo interesting, such that lack of context proves all the more how context is itself an eidetic feature of a photograph. Furthermore, the concerns of commodification and whether or not photography is ever an art, which have surrounded reflections on the photograph with suspicion since at least Walter Benjamin, only find expression once this feature is acknowledged. Still a full account of photographic context is better suited for an amplitive phenomenological investigation than the present eidetic one.

What, then, characterizes context as an eidetic feature of photographs? Above all it is their insertion into the meaningful matrix that has come to be known as the lived world. Context is the how of this relation to meaningfulness. Since it is here that one finds the significance of photography for contemporary culture, this is why so much reflection has been directed precisely at this feature of photography.

Before turning to examine technology I want to note a strange, but immediate, implication of this thesis: a photograph is not a photograph unless human beings are involved. While one can imagine the existence of both the physical image and the image object, the image subject disappears without the lived world. Here one may speak analogously of a photograph, but 
the item that makes up what one perceives in lived experience cannot be extricated from this meaningful context, and therefore does not, strictly speaking, exist apart from it.

\section{Technology}

As a cultural artifact, the photograph cannot be divorced from its technological dimension. I do not mean to focus here on the fact that the photograph may be a product of techne understood as artisanship, but rather on the fact that even the daguerreotype was not possible without a certain understanding of optics and chemistry. In addressing the photograph, then, the relation of the image to technology is complex. This point thus raises a difficult question: just what is the function of technology in photography?

While there is much to be said of the way in which technology and the photograph have emerged as a kind of joined project, the present inquiry must focus on only those aspects that are

both universal and necessary for a photograph. ${ }^{21}$ I thus want to focus on how technology is an ingredient in the production of the photograph in a phenomenological way. Perhaps one can begin with a commonplace example.

As anyone knows - anyone who has ever taken a bad photograph or who knows of people who always look better in front of a camera than in "real" life-there always seems to be a gap between a scene and its depiction (Darstellung) in a photograph. This point illustrates what I take to be the technological ingredient in a photograph: that it produces a certain moment of alienation for the representative structure (and it is in this sense that I intend to recover Barthes' account of the punctum as an always present but unintended aspect of a photograph). ${ }^{22}$ This alienating is not the alienating mode of our technologizing epoch. Rather, I want to note the way that, in a photograph, there is a necessary moment of delay between the aim or intention of the 
photographer and the photograph produced. This is why one sees professional photographers who take up to five shots a second at sports events. What is produced is ultimately beyond the grasp of the photographer. She must always wait in suspense to see if the image "turns out." Because technology is required to inscribe the photograph, an autonomous process intervenes to produce the product.

Technology, then, is constitutive of photographic inscription — at a phenomenological level—as a delay or distanciation at its heart. It is this delay which constitutes the photo's positive moment of alienation. What may yet be unclear is why it is that this interruption by an autonomous function is a positive moment. My answer is two-fold. First, it is positive because without it, photography would be impossible. Second, because it enables the representative transformation of the visual field, which I would like to flesh out by turning to the last eidetic feature.

\section{$X$. The Visual Field}

Both the image object and image subject of a photograph must appear in a visual field. Obvious though this point is, I mention it not only because it is true, but also because it is deceptively false. The visual field of a photograph is a transformed field. Is it not the case that even pictures of garbage and waste become something to which one will attend in a photo, though in life one would just pass by such things? Somehow what was not worth seeing, something that goes unseen in lived experience, comes to show itself in a photo. ${ }^{23}$ What is one to make of this feature of photographs? Does a photo transform the visual field by highlighting what is shown? Is it the consequence of the frame (which fixes the indefinite proliferation of profiles) that the visual field of a photograph gains significance? More strongly phrased, is this 
consequence of the transformation of the visible field not the making visible its invisible significance $?^{24}$

This hypothesis is almost true. Presumably, photographs are of something that one can see or could see with the naked eye. One thinks of family portraits or landscapes. The use of photography in the sciences, however, shatters this notion. Not only are there photographs of much that cannot be humanly seen, because they are too small (e.g. plant cells, bacteria, atoms), there are even photographs of images that do not appear within the visible light spectrum (e.g. infrared or ultraviolet astronomical phenomena). Their representation to the human eye, then, becomes a matter of transposing certain electromagnetic relations into relations that are visible. While this may appear to be a particular case, one notes that even in the ordinary photograph, something that was not visible becomes visible. In one's lived experience, one only notices certain details, but the photo records them all, including those that go unnoticed as well. Alexander Gardner's famous photo of Lewis Payne makes this point nicely, since while it is natural here to focus on Mr. Payne himself, one also finds that indeed most of the visual field is just a mass of metal plating with rivets and dents. Thus the visual field of a photograph is transformed, but not only by gaining significance, since the visual field of a photograph can represent what could never appear to the human eye (the infrared, the detail).

In a line, then, I argue that in a photograph the visual field is both the invisibility of the lived visible, marking its significance, and the lived visibility of the invisible, since it brings to lived experience what was formerly inaccessible. 


\section{The Consequences of the Present Eidetic Phenomenology}

The foregoing eight features of a photograph are what I take to be its eidetic components, namely image inscription, framing, spatiality, temporality, minimally empty intentionality, meaningful contextualization, technological delay, and appearance within a transformed visual field. I let them stand as the payment due for the promissory note Barthes "signed" some time ago. I hope that I have not gone too far wrong in their adumbration, but in the spirit of a corrigible phenomenology I welcome correction through intelligent exchange as the best way to accomplish the eidetic reduction. I want now to spell out some consequences of the foregoing investigation.

To begin, I recall that the photograph appears through an achronic time. That it occurs in the moment, as defined above, means that it escapes Heidegger's critique of metaphysical time. In $\S 81$ of Being and Time Heidegger argues that the vulgar conception of time (vulgäre Zeitverständis) “is understood as a succession, as a 'flowing stream' of 'nows,"” which is what I have above called "chronic time" (422/474). This conception levels off (nivelliert) even the datability and significance belonging to within-time-ness (Innerzeitigkeit), which is the most derivative of the three fundamental notions of time considered at the end of Being and Time. ${ }^{25}$ Such chronic time, Heidegger argues, is typified in the image of eternity that Plato announces in his Timaeus (37d), and it characterizes time as something present-at-hand (423/475). The foregoing phenomenology, however, suggests that in a photograph one perceives a novel form of non-metaphysical time that approaches the status of what Plato in the Parmenides called to exaiphnēs or "the moment" (155e-157b). There the moment is that which accounts for the possibility of the One to partake of temporal determinations, and so it works to overcome the distinction between the sensible and the intelligible. ${ }^{26}$ In a similar vein here, I argue that this 
achronic time accounts for the possibility of photographic representation in a perceiver's visual field. One is immediately introduced into a temporal determination that is not the present-athand sequence of nows, so that this moment is not complicit with the covering-over (Verdeckung) of the more fundamental senses of time.

A first consequence of the foregoing account of the moment is thus that reflection on the status of this form of time, especially since images are so pervasive today, may fruitfully lead the way to making a crossing to the other beginning, which is another way of saying that it could contribute to the overcoming of ontotheology. Heidegger, in his Contributions to Philosophy makes clear that to his mind the first beginning, which comes to be called metaphysics, occurs through the Platonic determination of being as idea, which establishes the fundamental distinction between the intelligible and the sensible (\$§109-110). To his mind, this epoch finds its culmination in Nietzsche's thought when the distinction between the intelligible and sensible is reversed (§89). The first beginning, nevertheless, is not a simple beginning since it was already a transformation of truth as alettheia into idea (§91). The first beginning is thus first only in relation to the other beginning that the Contributions to Philosophy are meant to prepare. ${ }^{27}$ This other beginning "overcomes" metaphysics by twisting-free from it, which is to say that it is a return to the first beginning so as to think in it what remains unthought. "The first beginning," writes Heidegger, "experiences and posits the truth of beings, without inquiring into truth as such" (§91). What is decisive is a regression from the intelligible-sensible framework that governs metaphysics, that governs the determination of alettheia as idea, to what remained concealed within that framework. My proposal here is that because the moment of photography already escapes the metaphysical determination of time as a sequence of nows, as chronos, it 
might be possible to use this form of time as a point of departure for a crossing over into the other beginning as Heidegger lays out in his Contributions.

Second, I note that the moment of positive alienation that characterizes the technological function of a photograph connects suggestively with the transformation of the visual field and a photograph's general representative structure - what one finds is the amplification of lived experience through distance and delay. By transforming the aesthetic field, a new reality emerges, one that exceeds the lived visible in order to restore it to the viewer in another (lived) form in the photograph, and which does so in a way that is beyond one's control. I think that this point justifies one in concluding that the photograph has the quality of an event, and one that results directly from its technological function. By "event" here I have in mind a notion along the lines that Badiou lays out in Being and Event and Logics of Worlds rather than Heidegger's Ereignis. For Badiou, at base, an event is an unpredictable and unforeseeable occurrence of true change. There are, one may say, three aspects to an event's occurrence: (1) localization in a site in a world, (2) the occurrence of the event (as sustained by the subject), and (3) a process of intervention. ${ }^{28}$ Since my approach is phenomenological, unlike Badiou's, one will expect to find a few differences. Nevertheless, the photograph occurs at a visual site in a world and exploits the inexistent appearance of naked-eye lived visibility, which makes up the overwhelming amount of experience that is non-thematically present in one's lived experience. The taking of the photograph along with its technological inscription makes for the occurrence of the event. And the result transforms one's lived experience into a new visual field. Though much discussion of late has concerned the status of events, none to my knowledge has looked to the role technology plays in them. ${ }^{29}$ This means, of course, that Heidegger's account of technology must be 
redressed, but the present phenomenology nevertheless suggests a fruitful avenue for research here.

Third, while I am certainly not the first to hint that Heidegger's account of the relation between art and technology as modes of alētheia is in need of rectification, what the foregoing suggests is a certain dislocation of truth. ${ }^{30}$ Heidegger recalls that the "phenomenon" signifies "that which shows itself in itself, the manifest" (Heidegger, Being and Time 51). And a little later he writes: "[t]his kind of showing-itself is what we call shining [Scheinen]" (51 translation modified). My analysis shows that in a photograph one finds a form of manifestation that produces a new form of appearance (Ersheinung), a transformed appearance, which occurs through the distanciation wrought by a technological event. The shining of this appearance, its truth, is thus dislocated from its position as something one encounters in the finitude of the strife between clearing (Lichtung) and concealing (Verbergung), and instead takes place in the transformation wrought by an event. To state the significance of this consequence plainly: it suggests that the essence of truth is not finite, not definable through a correlation of revealing and concealing, but rather is infinite, the result of an unpredictable, unforeseeable event. What marks this event's difference from Heidegger's later account of Ereignis is that the event of the photograph is also nothing without the tangible result of transformation (the third aspect of Badiou's event above). The sense of the infinite here is something I take from Badiou, and which I am trying to capture phenomenologically. ${ }^{31}$ Critical to this account is what Badiou calls the matter of "consequence," which means that an event is not an event without a transformation in the world of appearance. ${ }^{32}$ It is not, and cannot be, the structuring of epochs of meaning, since this structuring is always caught in the double play of non-essence and essence, of concealing and revealing. Heidegger's Ereignis, as John Sallis shows so clearly, is something one always 
meets at the limit or on the verge, and dwelling there marks thought's most profound calling. ${ }^{33}$ Here, the photographic event, wrought by technology, is visible even to the photographer only though the consequences. There is no interplay between the concealed and revealed, only novel transformation, and this is what marks the self-showing of the photographic phenomenon as fundamentally different from Heidegger's account, why it is infinite rather than finite. Whether it ultimately has the character Badiou claims is another matter, but the shift indicated here marks a profound consequence for phenomenological inquiry.

The final consequence of the foregoing investigation, then, is the use to which an eidetic phenomenology may be put. While popular opinion has it that a description of eidetic features only shuts down thought and attempts to hem in what will always exceed those boundaries, if the foregoing is at all correct, then it can be seen that the way in which I have used an eidetic phenomenology is quite different. Though my account is admittedly corrigible, a focus on the eidetic nevertheless has implications for the very showing forth of phenomena, and so questions one of the most entrenched motifs of Continental philosophy: the finitude of truth. What I hope to have shown then, is that the eidetic is a field for research that is just like any other field, say gender or saturated phenomena, and may yield fruitful results despite its corrigibility. Furthermore, as my distinction between the eidetic and the amplitive has shown, even if the eidetic is taken to be "foundational" in the sense that all phenomena of a certain kind must exhibit certain features, it cannot be foundational in a Cartesian sense, since there are other domains, such as the amplitive, that address features of phenomena that the eidetic cannot, and which are often times more interesting. Thus one cannot hope to address what is most important simply by addressing the eidetic, and this shatters the Cartesian epistemic dream of finding one solid point on which to build a philosophic edifice. Instead the new home for eidetic 
phenomenology is to be found only in the strategic uses to which it is put. Thus, while many of the foregoing conclusions remain provisional, the possibilities that they engender are not, and I hope that this conclusion might open the way to a new form of phenomenology.

\section{Notes}

${ }^{1}$ See Derrida's essay “The Deaths of Roland Barthes."

2 See Maynard's The Engine of Visualization: Thinking Through Photography where he argues that Camera Lucida is "actually reductive to the subjects photographed, taken substantively: usually people or details of them and their attire" (13).

3 See Shawcross' compelling Roland Barthes on Photography: The Critical Tradition in Perspective.

${ }^{4}$ See for this point the following essays: Michael Fried's "Barthes's Punctum," James Elkin's excellent response in "What do We Want Photography to Be? A Response to Michael Fried," and Andrew Fisher's "Beyond Barthes: Rethinking the Phenomenology of the Photograph."

${ }^{5}$ I have in mind principally Heidegger's statements on truth in his essay "On the Essence of Truth."

6 For an example of the former see Jacques Derrida's Speech and Phenomena, especially chapters three and four. For the latter case, the locus classicus is of course Martin Heidegger's History of the Concept of Time: Prolegomena, especially sections 11-13.

${ }^{7}$ See for example: Michel Foucault's introduction to the English translation of Herculine Barbin, Judith Butler's critique of "essentialism" in Gender Trouble, bell hook's Ain't I a Woman, and more recently the work by Sally Hasslanger, such as "Gender and Race: (What) Are They? (What) Do We Want Them To Be?", and Johanna Oksala especially in her "Phenomenology of Gender."

${ }^{8}$ For Ricoeur's earliest and perhaps clearest statement on the matter, see his essay "Existence and Hermeneutics." For the best example of this method in action, however, one should instead look to the opening phenomenology of memory in Memory, History, Forgetting.

${ }^{9}$ For both the compatibility of phenomenological descriptions with the "theory ladenness" of description, and the corrigibility of these descriptions see the "Introduction" to Claude Romano's L'évément et le temps. 
${ }^{10}$ See the "Introduction" to Immanuel Kant's Critique of Pure Reason page B4 for his explicit statement on the unity of both universality and necessity in the a priori.

${ }^{11}$ On this point see especially section IV of Book I in Hume's A Treatise of Human Nature.

${ }^{12}$ It is tempting to understand the present account of "invariance" that characterizes amplitive phenomena as retaining only the universal character of the Kantian a priori, but one ought to remain on guard against this strict equivalence for two reasons. First, the conceptual matrix in which Kant announces the a priori only makes sense given his assumptions about the character of the givenness of phenomena, and especially his presupposition that human knowing contains two branches (intuition and the categories). To assume equivalence would thus risk syncretism. Second, the invariant I have in mind clearly requires a scope within which it must operate, so that it is not universal for all phenomena. I leave as an open question here how one is to determine the extent of this scope, which would have been troubling for Husserl, but my sense is that this matter must be addressed on a case by case basis. Each amplitive phenomenological investigation should, to my mind, establish the scope of that investigation as its necessary point of departure.

13 In opposition to Andrew Fisher, who in "Beyond Barthes" argues that Barthes implicitly uses an existential rather than eidetic phenomenology, I hold that Barthes in fact undertakes an amplitive phenomenology of the photograph by paying attention to the contingent but qualitatively differentiated way in which photographs affectively act on the viewer.

14 This is a point that I take from Hubert Damish's "Five Notes for a Phenomenology of the Photographic Image" (288).

${ }^{15}$ I have in mind here the process of simulation that Jean Baudrillard describes in the opening chapter of Simulacra and Simulation.

${ }^{16}$ As a defense of Marion one might respond here by noting the fact that Marion states (at least at one point) that "the appresented tends to disappear and leave the way entirely free for the presented" (63). My response is double. First, this tendency is not the same as his later claim that the frame reduces phenomenality to the pure visible (68). Second, even this tendency does not seem apparent to me. I simply apperceive the backside of the horse along with what is given. No tendency to reduce this apperceptive is present at all.

17 This is a relatively new art, but one can find numerous images as well as an account of its performance at http://www.lapp-pro.de/.

${ }^{18}$ For Heidegger's account of the vulgar conception of time, which he argues is Aristotle's account, see Being and Time section 81 and specifically page 422/474. 
19 For Husserl's account of inner time-consciousness, one should look to his On the Phenomenology of the Consciousness of Internal Time (1893-1917), especially the second section on the "Lectures on the Phenomenology of the Consciousness of Internal Time."

${ }^{20}$ This is a point that I have taken from the art historian Kirk Varnedoe, which he makes in his excellent Pictures of Nothing: Abstract Art Since Pollock.

${ }^{21}$ Don Ihde, in Postphenomenology, rather convincingly shows that the photograph functions as an experimental value for both science and technology. For more on this point see chapter four of that work.

${ }^{22}$ One may wonder just what happened to the pathetic dimension of the punctum that Barthes sees as so important. In the present work that dimension has been bracketed as suitable for an amplitive phenomenology but not an eidetic inquiry.

23 John Berger makes the case that at its heart a photograph means: "I have decided that this is worth recording" in "Understanding a Photograph" (292). While I cannot entirely agree with this point, the transformation of the ordinary scene in the photograph is what I take from this essay.

24 This is a point about which almost any phenomenological reflection on painting or photography has made. Perhaps the earliest and still the best is Michel Henry's statement in Seeing the Invisible: On Kandinsky.

${ }^{25}$ The other two are of course historicality (Geschichtlichkeit) and temporality, with this last as the most fundamental.

${ }^{26}$ Plato's Parmenides is notoriously difficult to interpret, but one may find an account of the moment that is sympathetic to my statement here in $\$ 2$ of Romano's L'événement et le temps.

${ }^{27}$ On the present matter I have found John Sallis' work on Heidegger's Contributions in his The Verge of Philosophy to be an invaluable guide.

${ }^{28}$ For the first two parts, the interested reader should see Badiou's exceptionally clear account in section one of Book V in Logics of Worlds. For his account of intervention as a theory of points and the formation of a subject body, one can look to the first sections of Books V and VII respectively of the same work, though the mathematics behind the theory of points draws on all that Badiou has presented previously in that work. I note that the present account of a three-fold character to events follows Bruno Bosteel's interpretation of Badiou rather than Peter Hallward's. For Bosteel's account see his essays "Vérité et forçage" and "On the Subject of the Dialectic."

${ }^{29}$ For those authors most concerned with the event, I have in mind Alain Badiou, Gilles Deleuze, Jean-Luc Marion, and Claude Romano. Only the first two mention technology in a positive light, though neither connects it to their account of events. 
${ }^{30}$ Of all the extant critiques of Heidegger's account of technology, it seems to me that Dominique Janicaud's Powers of the Rational: Science, Technology and the Future of Thought is the most careful and attentive to the root of the matter: truth. Yet, while I follow his exposition up to this point, I nevertheless depart from his suggested extension, since I am questioning the very adequacy of Heidegger's account of truth, which, in the sense that I have in mind, he does not.

${ }^{31}$ While Alain Badiou's critique of finitude has been something he has pursued beginning as early as his May $8^{\text {th }}$ and $15^{\text {th }}$ lectures of 1978 in Theory of the Subject, the clearest accounts can be found in his essays "The (Re)Turn of Philosophy Itself," "Definition of Philosophy," and "Philosophy and Mathematics" all in Conditions.

${ }^{32}$ See especially section one of Book V in Badiou's Logics of Worlds for an account of consequence and its significance for determining both the actual occurrence of events as well as their strength.

${ }^{33}$ This point is something one finds most clearly in the opening and closing chapters of John Sallis' The Verge of Philosophy.

\section{Works Cited}

Badiou, Alain. Being and Event. Trans. Oliver Feltham. New York: Continuum Press, 2005.

—. Conditions. Trans. Steven Corcoran. New York: Continuum Press, 2008.

—. Logics of Worlds. Trans. Alberto Toscano. New York: Continuum Press, 2009.

—. Theory of the Subject. Trans. Bruno Bosteels. New York: Continuum Press, 2009.

Barthes, Roland. Camera Lucida. Trans. Richard Howard. New York: Hill and Wang, 1982.

Baudrillard Jean. Simulacra and Simulation. Trans. Sheila Glaser. Ann Arbor: University of Michigan Press, 2004.

Berger, John. "Understanding a Photograph." Classic Essays on Photography. Ed. Alan Trachtenberg. New Haven: Leete's Island Books, 1980. 291-4.

Bosteels, Bruno. "Vérité et forçage: Badiou avec Heidegger et Lacan." Alain Badiou: Penser le multiple-Actes du Colloque de Bordeaux, 21-23 octobre 1999. Ed. Charles Ramond. Paris: L'Harmattan, 2002. 259-93. 
—. "On the Subject of the Dialectic." Think Again: Alain Badiou and the Future of Philosophy. Ed. Peter Hallward. London: Continuum Press, 2004. 150-64.

Butler, Judith. Gender Trouble: Feminism and the Subversion of Identity. New York and London: Routledge Classics, 1999.

Carter, Kevin. Untitled. Originally published in The New York Times, March 26, 1993. http://digitalfilmmaker.net/bang/bang_frame.html. April 11, 2010.

Damish, Hubert. "Five Notes for a Phenomenology of the Photographic Image." Classical Essays on Photography. Ed. Alan Trachtenberg. New Haven: Leete's Island Books, 1980. 287-90.

Derrida, Jacques. "The Deaths of Roland Barthes." The Work of Mourning. Ed. Pascale-Anne Brault and Michael Naas. Trans. Pascale-Anne Brault. Chicago: University of Chicago Press, 2003. 31-68.

- Speech and Phenomena. Trans. David B. Allison. Evanston: Northwestern University Press, 1973.

Elkin, James. "What do We Want Photography to Be? A Response to Michael Fried." Critical Inquiry, no. 31 (2005): 938-956.

Foucault, Michel. Herculine Barbin (Being the Recently Discovered Memoirs of a Nineteenth Century French Hermaphrodite). Trans. Richard McDougall. New York: Pantheon, 1980.

Fried, Michael. “Barthes's Punctum.” Critical Inquiry, no. 31 (2005): 539-574.

Fisher, Andrew. "Beyond Barthes: Rethinking the Phenomenology of the Photograph." Radical Philosophy, no. 148 (2008): 19-29.

Haslanger, Sally. "Gender and Race: (What) Are They? (What) Do We Want Them To Be?" Noûs, no. 34 (2000): 31-55.

Heidegger, Martin. Being and Time. Trans. John Macquarrie and Edward Robinson. New York: Harper and Row Publishers, 1962.

- Contributions to Philosophy (From Enowning). Trans. Parvis Emad and Kenneth Maly (Bloomington and Indianapolis: Indiana University Press, 1999)

- History of the Concept of Time: Prolegomena. Trans. Theodore Kisiel. Bloomington and Indianapolis: Indiana University Press, 1985. 
__, "On the Essence of Truth.” Trans. John Salllis. Pathmarks, ed. William McNeill. New York: Cambridge University Press, 1998. 136-54.

Henry, Michel. Seeing the Invisible: On Kandinsky. Trans. Scott Davidson. New York: Continuum Press, 2009.

hooks, bell. Ain't I a Woman: Black Women and Feminism. Boston: South End Press, 1999.

Hume, David. A Treatise of Human Nature. New York: Penguin Books, 1969.

Husserl, Edmund. Experience and Judgment. Trans. James S. Churchill and Karl Ameriks. Evanston: Northwestern University Press, 1973.

- On the Phenomenology of the Consciousness of Internal Time (1893-1917). Trans. John Brough. Boston: Kluwer Publishers, 1991.

- Phantasy, Image Consciousness, and Memory (1898-1925). Trans. John B. Brough. The Netherlands: Springer, 2005.

Ihde, Don. Postphenomenology: Essays in the Postmodern Context. Evanston: Northwestern University Press, 1993.

Janicaud, Dominique. Powers of the Rational: Science, Technology and the Future of Thought. Trans. Peg Birmingham and Elizabeth Birmingham. Bloomington: Indiana University Press, 1994.

Kant, Immanuel. Critique of Pure Reason. Trans. Norman Kemp Smith. Boston: Bedford and St. Martin's, 1929.

Marion, Jean-Luc. "The Idol or the Radiance of the Painting." In Excess: Studies of Saturated Phenomena. Trans. Robyn Horner and Vincent Berraud. New York: Fordham University Press, 2002. 54-81.

Maynard, Patrick. The Engine of Visualization: Thinking Through Photography. Ithaca: Cornell University Press, 2005.

Miedza, Joerg and JanLeonardo Woellert. Untitled. LAPP-PRO, 2007. http://www.lapp-pro.de. April 11, 2009.

Naifeh, Steven and Gregory White Smith. Jackson Pollock: An American Saga. New York: Clarkson N. Potter, 1989.

Oksala, Johanna. "Phenomenology of Gender." Continental Philosophy Review, no. 39 (2006): 229-244. 
Plato. Plato's Parmenides. Trans. Albert Keith Whitaker. Newburyport: Focus Publishing, 1996.

—. The Republic of Plato. Trans. Allan Bloom. New York: Basic Books, 1968.

—. Plato’s Timaeus. Trans. Peter Kalkavage. Newburyport: Focus Publishing, 2001.

Rancière, Jacques. The Future of the Image. Trans. Gregory Elliott. New York: Verso Press, 2007.

Ricoeur, Paul. "Existence and Hermeneutics." The Conflict of Interpretations. Ed. Don Ihde. Trans. Kathleen McLaughlin. Evanston: Northwestern University Press, 3-24.

- Memory, History, Forgetting. Trans. Kathleen Blamey and David Pellauer. Chicago: University of Chicago Press, 2004.

Romano, Claude. L'évément et le temps. Paris: Presses Universitaires de France, 1999.

Sallis, John. The Verge of Philosophy. Chicago: University of Chicago Press, 2008.

Shawcross, Nancy. Roland Barthes on Photography: The Critical Tradition in Perspective. Gainesville: University of Florida Press, 1997.

Varnedoe, Kirk. Pictures of Nothing: Abstract Art Since Pollock. Princeton: Princeton University Press, 2006. 